\title{
THE IMPACT OF VGM (VERIFIED GROSS MASS) IMPLEMENTATION AS SOLAS'S NEW REGULATION - CASE STUDY AT PORT OF TG.PRIOK
}

\author{
Rahmatika $^{1}$, Rindayu Alvita Putri ${ }^{2}$, David P Sirait ${ }^{3}$, Aswanti Setyawati ${ }^{4}$ \\ 1.STMT Trisakti, 2. STMT Trisakti, 3. STMT Trisakti, 4. STMT Trisakti \\ Corresponding author: rahmatikaramtik@gmail.com
}

\begin{abstract}
Safety is crucial in the shipping industry, however in the current export container activity there are many factors that can cause an accident. To prevent an accident, regulation play an important role. With regulation, safety can be implemented to decrease the risk. Therefore, IMO has amended the SOLAS's regulation that requires the shipper of a packed container to provide the carrier with the Container's Verified Gross Mass (VGM) before the stowage on board of a ship. The purpose of this study was to examine the impact of VGM implementation at port of Tg. Priok. By Using qualitative descriptive method, it is concluded that there are some differences before and after this regulation is implemented and VGM regulation implementation also affect the port charge for the shipping process at Port of Tg. Priok.

Keywords : Regulation, Safety, Risk, VGM, Export Container, and Port Charge
\end{abstract}

\section{Introduction}

From a national economic perspective, sea transport plays a significant role. It is a key facilitator in Global Trade. The flow of Goods continues to increase, ship design is getting bigger and goods are transported variously. (Nurtjahjo, Rianto; SE, 2016)

Global Trading with sea transportation may be the most widely used in the world especially container shipping activity, but this industry is also the most dangerous. Safety has often been a big concern in the shipping industry and especially in container shipping. For such an important maritime business, ensuring its safety and security and minimising the risks and the potential losses caused by the incidents in shipping operations is undoubtedly an issue of great importance. (Chang, Xu, \& Song, 2014)

According to World Shipping Council (WSC) Survey, The most recent 2017 survey gathered input for 2014, 2015 and 2016. All WSC member companies responded, and additional information was made available on certain non-member catastrophic events. For each of the three 
years surveyed, the average number of containers lost at sea excluding catastrophic events was 612 , which is about $16 \%$ less than the average of 733 units lost each year for the previous three year period. When catastrophic losses are included, the total containers lost at sea averaged 1,390 with $56 \%$ of those lost being attributed to catastrophic events. This is a $48 \%$ reduction from the average annual total losses of 2,683 estimated in 2014. (World Shipping Council,2017)

Shipper must provide the weight container contained in the shipping document in order to loaded the cargo on to the ship. According to United Nation Trade Statistic Compilation Data (1997 - 2015), shipping container activity with an incorrect weight are increasing from year to year, in 2015, it is estimated that 16.300.000 TEUs of cargo shipped without an accurate weight or that means "misdeclaration", and misdeclaration occurs when the actual weight of a packed container is different from the shipping document. When the declared weight by the shipper is more than actual weight then there is "overweight" which may have a serious effect on the stability of the vessel and this can pose safety concerns at the port.

Regulation is needed in order to achieve the compliance of safety and decreased the risks. Regulation has an important role in export activities. Therefore, IMO (International Maritime Organization) has amendment the regulation of the Safety of Life at Sea (SOLAS) Chapter VI, Part A, regulation 2 about Verified Gross Mass (VGM). Verified Gross Mass Means the total Gross Mass of a packed container as obtained by one of the method. The methods are by weighing the container after packing and sealing using calibrated and certified equipment or the second method by weighing all packages and cargo items including palletes and adding the tare weight of the container to that sum. (Albert Embankment, 2014)

Indonesia officially implemented the VGM on 1st July, 2016 through the regulation of the Director General of Sea Transportation. HK.103 / 2/4 / DJPL_16 concerning VGM transported on board. In the rule deciding in article 3 that before the container is loaded onto the vessel, the 
shipper is responsible for the verified container's carrying weight and the charge shall not be transported if the container master or container has not gained and knows the actual gross weight of the verified container, before the cargo loaded to the ship.

Effective regulation is related to openly supervised policies, regulations and laws backed by a credible provision to produce an expected outcome. These results can be cost efficiency, increase or risk. (Sheetal Radia, 2011). In the application of VGM Regulation at Tg port. Priok, it is estimated that there are several container terminal operations that make the regulation as a commercial activity by charging VGM fees to weigh and certify the container.

An efficient and effective transportation is important in order to create transportation operational costs at a minimum level, and the most appropriate transportation is by sea transport.(Thamrin, n.d.) However, instead for the safety, in its application at Port of Tg. Priok, it is suspected that export container services incur high costs due to VGM Implementation.

\section{Literature Review}

The Safety Of Life At Sea (SOLAS) regulation is the most important maritime safety regulation in order to improve the safety of marine life that began in 1914, since, at that time, there were many shipping accidents. (Lasse \& Darunanto, n.d.)

One of the causes of the accident both aboard and port is Misdeclaration of Container's weight and it have been considered as the most significant Risk for container shipping. (Paper, Law, \& Law, 2014)

To ensure the safety of the ship, the safety of workers both aboard ships and ashore, the safety of cargo and overall safety at sea, the International Convention for the Safety of Life at Sea (SOLAS), as amended, requires in chapter VI, part A, regulation 2 that packed containers' gross mass are verified prior to stowage aboard ship. The shipper is 
responsible for the verification of the gross mass of a container carrying cargo ("a packed container"). (Regarding et al., 2014)

Basicly, Shipper using the container to reduce the packing cost and port charge. In container container services in ports some of the charges are charged to the shipper / consignee in the container service process, such as Terminal Handling Charge, Document Fee, Lift on / Lift off charge, and so on. (Patiung, Darma, \& Sampel, n.d.)

\section{Method}

This research uses qualitative descriptive by using primary data obtained from PTP (Port of Tanjung Priok), JICT (Jakarta International Container Terminal), NPCT 1 (New Priok Container Terminal 1), MAL (Mustika Alam Lestari), and TPK Koja (Container Terminal Koja) by conducting a deep interview, FGD with the authorities, and direct field observation. The research also uses secondary data obtained from forwarding parties who have started implementing VGM services.

Qualitative research is characterised by its aims, which relate to understanding some aspect of social life, and its methods which (in general) generate words, rather than numbers, as data for analysis.(Bricki \& Green, 2007)

\section{Discussion and Result}

A. The Implementation of VGM Procedure the initial phase and trial phase are presented in the following figure.

VGM Procedure

In the application of VGM in Port of Tg. Priok is done in 2 Phase that are Trial Phase and Continued Phase. 


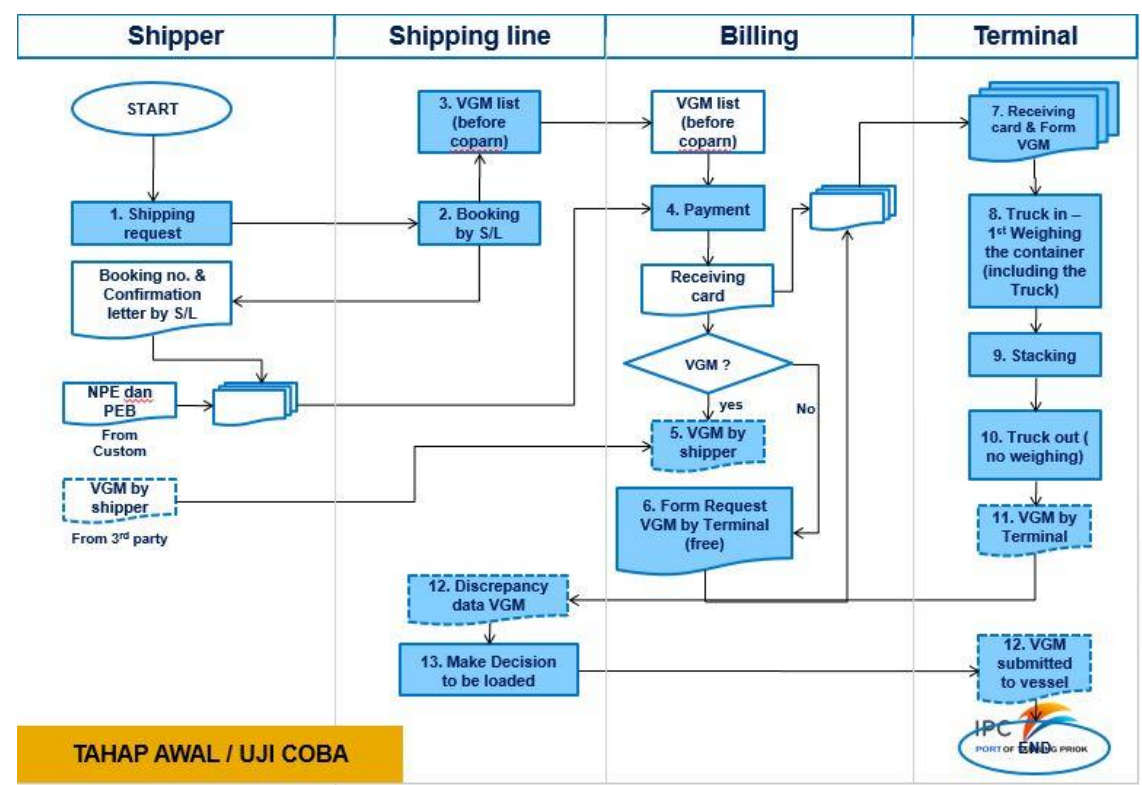

Figure. 1 Implementation VGM Procedure on Trial phase

- Shipper is required to provide VGM data - VGM certification documents submitted in billing

- COPARN is not (yet) mandatory

- A one-time weighing is done in the gate in

- Not subject to tariff of VGM data presentation by terminal Not subject to penalty rates against the discrepancy of VGM shipper data and terminal weighing

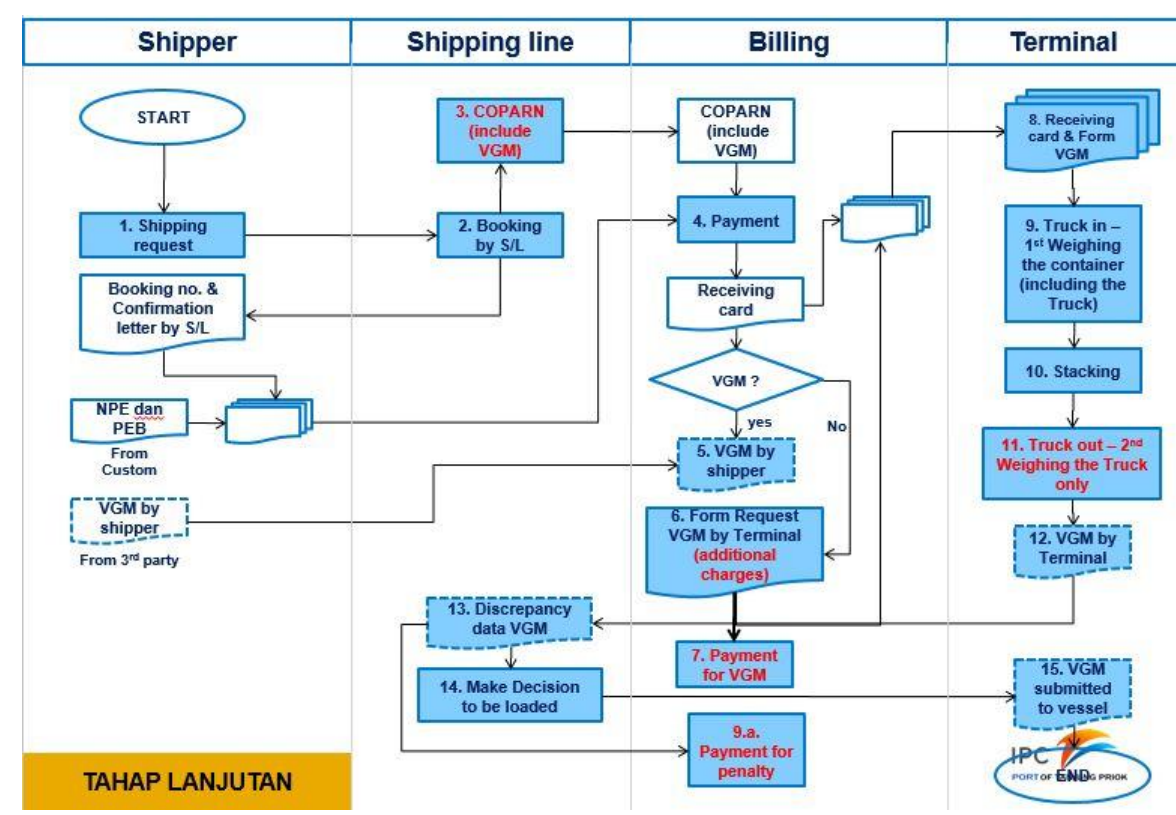

Figure.2 Implementation VGM Procedure on Continued stage

Source: Indonesian Port Corporation, 2017 
- Shipper is required to provide VGM data - VGM data sent to shipping line $\rightarrow$ to terminal via COPARN and VGM certification documents submitted in billing

- Coparn is mandatory

- Twice weighing in the gate in and in the gate outakan dikenakan tarif penyajian data VGM oleh terminal

- Will be subject to a penalty rate for discrepancies (up to 5\%) of VGM shipper data and terminal weighing

B. Comparison before and after VGM Implementation

VGM is applied for safety of shipping container activity to reduce the risk that often occurs due to misdeclare of container's weight. However, not all regulations go according to their objectives. Based on the results of interviews with several authorities at the port of Tg. Priok and several sources of articles obtained by authors from related companies, the following are comparison of the situation before and after the existence of VGM regulation, to prove the effectiveness and efficiency regulation in the port tg.priok.

Table. 1

Comparison Tables Before and After VGM Implementation at Port of Tg. Priok

\begin{tabular}{|l|l|}
\hline \multicolumn{1}{|c|}{ Before } & \multicolumn{1}{c|}{ After } \\
\hline $\begin{array}{l}\text { Port of Tg. Priok do the weighing Container } \\
\text { in Gate in for furthermore use as reference } \\
\text { container placement on board. }\end{array}$ & $\begin{array}{l}\text { Weighing is not only done on Gate In, but } \\
\text { also in Gate Out to prove that the weight of } \\
\text { the container is declared accurately by } \\
\text { weighing the weight of the axle truck, as a } \\
\text { deduction from the weighing result on Gate } \\
\text { In. }\end{array}$ \\
\hline $\begin{array}{l}\text { There is no certification for container } \\
\text { weight }\end{array}$ & $\begin{array}{l}\text { An official VGM (Verified Gross Mass) } \\
\text { certification is required as a condition of } \\
\text { container loaded onto the Ship }\end{array}$ \\
\hline $\begin{array}{l}\text { No charge for weighing the weight of the } \\
\text { container }\end{array}$ & $\begin{array}{l}\text { At some of the terminals in Tg.priok took a } \\
\text { charge for weighing rates and certification } \\
\text { services after VGM regulation is enforced, } \\
\text { for reasons of additional weighing on Gate } \\
\text { Out }\end{array}$ \\
\hline
\end{tabular}


Table. 1, cont.

Comparison Tables Before and After VGM Implementation at Port of Tg. Priok

The receiveing process is not as complicated as VGM process, since weighing is only done in gate in and truck can carry the load on exit terminal. So it is more effective and efficient.

Sometimes misdeclaration of conainer's weight happen and this situation can lead to the unstability of the ship
The occurrence of complexity and ineffective and efficient in this VGM process, because the terminal must be done two times weighing on the gate in and gate out. The VGM process takes 45 minutes, starting from the weighing line to the stacking. It included a container truck out of the terminal.

All Parties (Carriers and Terminal Representative) can get an accurate and accountable weight so the risk of unstability of the ship will be reduced

From the comparison results before and after the implementation of VGM in Port of Tg. Priok, it can be concluded that there are positive and negative impacts arising from the implementation of this regulation. The positive impact are the Shipping will get accurate weight of goods so that the calculation of the stability of the ship can be more accountable, the port terminal will also get accurate weight container data from every container so as to prepare the most appropriate loading and unloading equipment, will also get a more definite load so that the truck driver can drive his truck on the road more safely and comfortably. This positive impact will decreased the risk that occurs due to heavy container misdeclare, so safety can be increased.

While the negative impact is, for a particular shipper that the sale and purchase agreement of goods not based on tonnage it will provide additional cost burden because they have to weigh the goods and containers that will be sent. Another negative impact is to add complexity in the process of importing goods to the terminal because each container must be weighed first after and before the load on the truck. 


\section{VGM Charge}

After VGM (Verified Gross Mass) applied in Indonesia, in the process of container service at Port of Tg. Priok, the researcher found a new cost that emerged in some container terminals related to the process of weighing container.

Table 2.

Comparison of VGM Service Charge in Port of Tg. Priok

\begin{tabular}{|l|l|l|}
\hline Teminal $\begin{array}{c}\text { VGM } \\
\text { Charge }\end{array}$ & Weighing Charge & Issued Certificate \\
\hline TO 3 Tg. Priok & \multicolumn{1}{|c|}{-} & - \\
\hline JICT & RP. 50.000 & Rp. 75. 000 \\
\hline MAL & Rp. 25.000 & Rp. 25.000 \\
\hline NPCT 1 & & - \\
\hline TPK Koja & Rp. 50.000 & Rp. 75.000 \\
\hline
\end{tabular}

Source : Primary Data, 2017

From the table above it is known that there are 3 of 5 terminals that take charge for this VGM Process, the terminal is JICT, MAL and TPK Koja. For the cost of weighing the container at JICT and TPK koja charged the same price of RP. 50.000 / box and Rp. 75.000 / box for the cost of certification services if the goods owner or exporter certifies VGM in the terminal. While at the terminal MAL charged the same of Rp. 25.000 / Box for weighing costs and certification services.

According to the FGD (Forum Group Discussion) results conducted with the operations director and staff of Terminal Operation 3 at Port of Tg. Priok, they argue that this difference in charge is due to the terminal that applied for VGM Charge is a Private Company where they invest in scales for commercial reasons. This is still a debate among the concerned parties, basically in the regulation of the Director General of 
Sea Transportation. HK.103 / 2/4 / DJPL_16 is not mentioned about the charge for this container weighing process and there is also no sentence stating prohibition if a terminal is wearing charga for this VGM process.

The existence of charge for the VGM process is not in line with cost efficiency which is one of the objectives in the implementation of regulation where one of the impact of regulation should be to reduce cost, not created new cost.

D. Container Accidents due to Overloading

VGM is a regulation made by IMO with the aim of reducing the risk of container and vessel accidents due to missdeclared weight container. missdeclared of weight container would be very dangerous if continuous, as happened in some ports and ships. Here's an example of the incident.

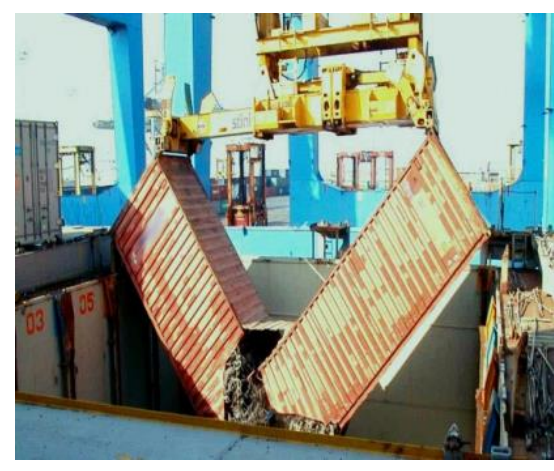

Source : https://theloadstar.co.uk, 2014

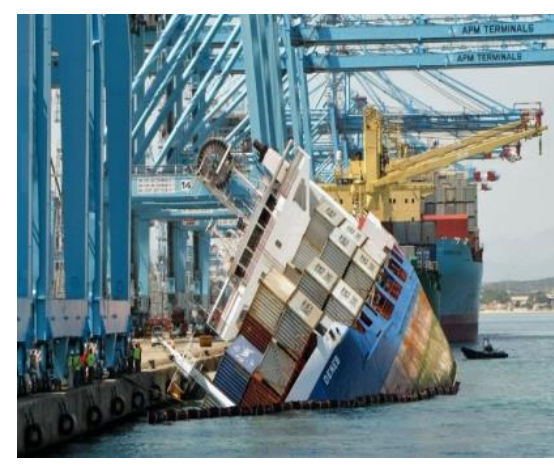

Source : https://www.linkedin.com, 2015

In the picture above there are two accidents that occur due to heavy declaration of container errors, there is an excess loa $d$ in Figure 1 that makes the container damaged and even broken when it will be transported by crane on board. That is the reason why heavy container verification should be applied so that the loads are transported in accordance with the capacity of the container in order to avoid overloading as shown above.

In Figure 2, the ship is sinking due to several factors, one of which is due to incorrect placement of charge. The load on board shall be placed 
in accordance with its weight to keep the vessel stability and no such thing as in figure 2.

From the above two images can be concluded that the heavy accuracy of the container becomes an important thing for security, both for the ship and the container itself. IMO has several times issued rules on the weight of containers, to arrive at the regulation of VGM. However, these two events are not happening in Tg port. Priok, but occurs in other countries. Thus, it can be concluded there is no major influence in term of safety for Port of Tg. Priok after the regulation of VGM because Port of Tg. Priok already apply the weighing procedure, and port of Tg. Priok applied VGM regulation as a fellow of International Maritime Organization.

\section{Conclusion}

From the result of this research it can be concluded that in Tg port. Priok implements VGM (Verified Gross Mass) in accordance with IMO regulations to improve safety in shipping activities, but the application of VGM in Port of Tg. Priok has no major impact since before the VGM, Port of $\mathrm{Tg}$. priok has to weigh the container in the gate in before the container is loaded onto the ship.

And another impact of VGM is the increment of charge in container service activity in some terminal at Tanjung Priok port which are weighing cost and certification issued cost. This raises the pros and cons in the related circles because one of the objectives of this regulation other than for safety is to increase efficiency, but on the contrary the application of this regulation becomes inefficient because it leads to new costs. This research need a further investigation of the implementation of VGM throughout the Port of Indonesia in a transparent and similar perception agreement involving relevant elements. (Regulators, Operators, Cargo Services). 


\section{References}

Bricki, N., \& Green, J. (2007). A Guide to Using Qualitative Research Methodology. Medecins Sans Frontieres, 11-13. https://doi.org/10.1109/PROC.1978.11033

Chang, C.-H., Xu, J., \& Song, D.-P. (2014). An analysis of safety and security risks in container shipping operations: A case study of Taiwan. Safety Science, 63, 168-178. https://doi.org/10.1016/j.ssci.2013.11.008

Lasse, D., \& Darunanto, D. (n.d.). BAGI ANAK BUAH KAPAL, 257-266.

Nurtjahjo, Rianto; SE, M. (2016). Dwelling Time, 220-228. Retrieved from http://sbm.binus.ac.id/2016/04/14/dwelling-time/

Paper, L. L. M. S., Law, T., \& Law, F. O. F. (2014). the Problem of Misdeclared Container Weight Llm Seminar Paper Laws 538: Maritime and Transport Law.

Patiung, R., Darma, R., \& Sampel, P. (n.d.). Peranan petikemas dalam menunjang ekspor impor komoditi hasil pertanian di pelabuhan soekarno hatta makassar.

Peraturan Dirjen Hubla tentang Berat Kotor Peti Kemas Terverifikasi yang Diangkut di Kapal.compressed (1).pdf. (n.d.).

Regarding, G., Verified, T. H. E., Mass, G., Cargo, C. C., Maritime, T., Committee, S., ... Governments, M. (2014). I:ICIRC\MSC $101 \backslash 1475 . d o c$, 44(0).

Thamrin, M. (n.d.). Kualitas Pelayanan Jasa Keagenan Kapal Dan Komunikasi Interpersonal Pada Services Quality of Ship Agency Services and Interpersonal Communication in Shipping Companies, $3(2), 217-225$.

http://www.cfauk.org (downloaded on November 01, 2017)

http://www.worldshipping.org (downloaded on November 12, 2017)

http://www.malt300.com (downloaded on November 12, 2017)

http://kpn.akpelni.ac.id (downloaded on November 14, 2017) 